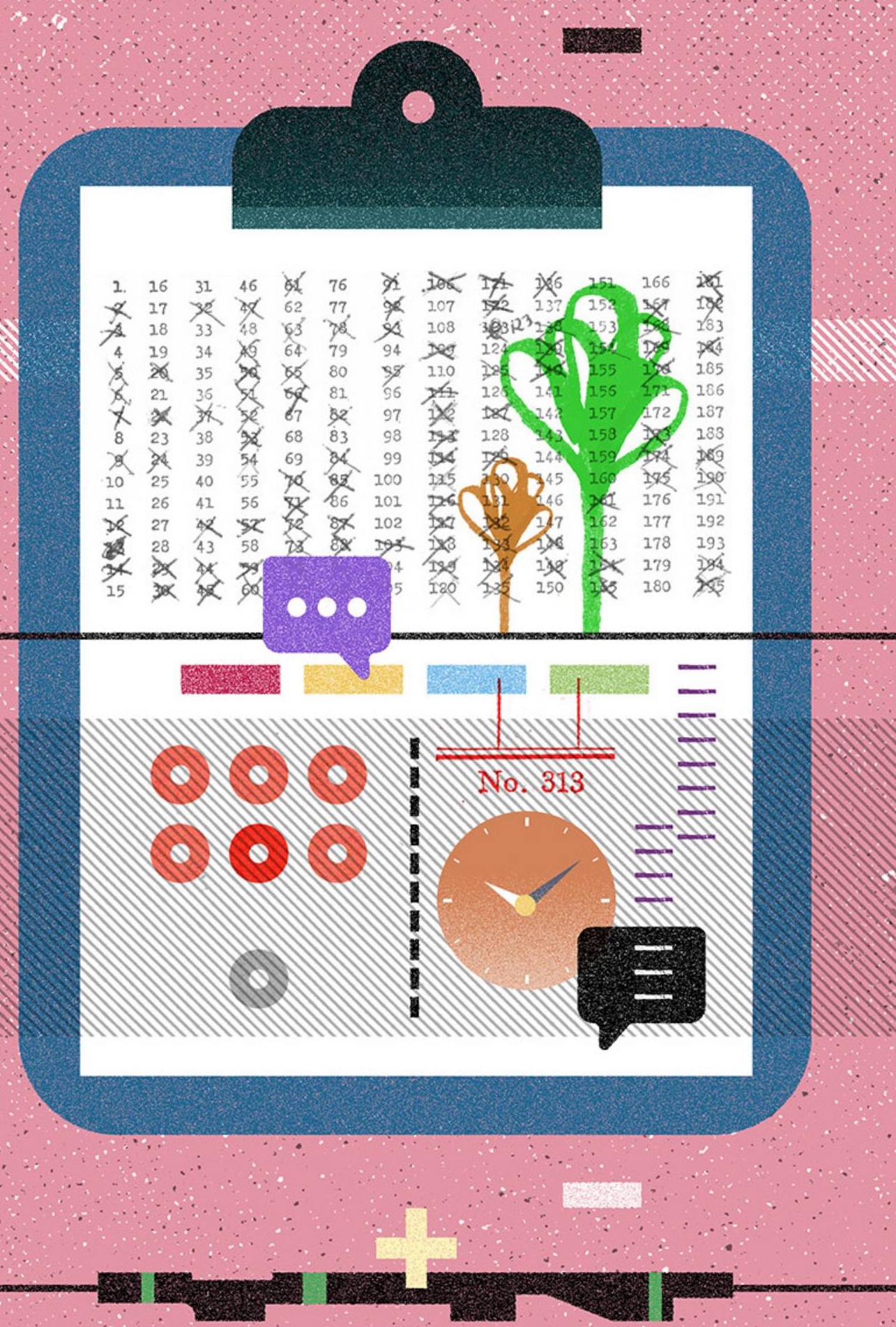




\title{
The Role of Public Administration in Environmental Governance: a Case Study based on the Institutional Analysis and Development Framework
}

\author{
O Papel da Administração Pública na \\ Governança Ambiental: Um Estudo de \\ Caso baseado no Quadro da Análise e \\ Desenvolvimento Institucional
}

\author{
Tomás de Oliveira Bredariol* | Valeria Gonçalves da Vinha **
}

\begin{abstract}
This article draws upon theory and a case study to research public administration's role in environmental governance systems. Thus, it examines Brazil's environmental regulation of the offshore oil and gas sector. The methodology used follows the Institutional Analysis and Development Framework and supports interviews, documentation review and direct observation. The results indicate the main features of the institutional setting, including the rules in use and relevant external variables. Concluding, three key elements operating at the organizational level are highlighted: the means of stakeholder participation; the stability and forms of interaction within the personnel; and the autonomy to enforce established arrangements.
\end{abstract}

Keywords: Environmental Governance; Public Policy; Institutional Development; Public Administration.

\begin{abstract}
Resumo
Este artigo se baseia em um estudo de caso para explorar o papel da administração pública em sistemas de governança ambiental, examinando a regulação ambiental brasileira do setor de petróleo e gás offshore. A metodologia utilizada segue o quadro da Análise e Desenvolvimento Institucional e compreende entrevistas, revisão documental e observação direta. Os resultados apresentam o ambiente institucional, incluindo as regras em uso e variáveis externas. Concluindo, três elementos que operam no nível organizacional são destacados: meios de participação das partes interessadas; estabilidade e formas de interação entre a equipe; e autonomia para garantir o cumprimento dos arranjos estabelecidos.
\end{abstract}

Palavras-chave: Governança Ambiental; Políticas Públicas; Desenvolvimento Institucional; Administração Pública.

\footnotetext{
* Environmental Engineer, M.Sc. in Public Policy, Strategies, Development and Sustainability. Environmental analyst at the Oil and Gas Production Coordination of the Brazilian Institute of Environment and Natural Renewable Resources (COPROD/IBAMA). https://orcid.org/0000-0003-2051-8571.

Email: breda@poli.ufrj.br (Corresponding author).

** Associate professor at the Institute of Economics of the Federal University of Rio de Janeiro and researcher at the National Institute of Science and Technology in Public Policies, Strategy and Development. She was a postdoctoral scholar at Columbia University (USA) and holds a PhD from the Graduate Program in Social Sciences in Development, Agriculture and Society of the Federal Rural University of Rio de Janeiro (CPDA / UFRRJ). Her research focuses on business strategies and sustainability; social-environmental regulation and self-regulation, and socio-environmental conflicts. https://orcid.org/0000-0001-6217-2471. Email: valeriagdavinha@gmail.com.
} 


\section{INTRODUCTION}

Governance as a concept has evolved from a view more centred on the nature and role of the state in policy making to a greater focus on the coordination of social systems to face major problems (Enroth 2014). This notion emphasizes the existence of networks and the importance of addressing dangers which often transcend standing collectivities and institutional arrangements.

In this context, the objective of this article is to provide further knowledge of how the public administration may fulfil its role in environmental governance systems. Moreover, the article uses a pluralist perspective of environmental governance (Davidson and Frickel 2004) in an attempt to identify important functions and features of regulatory agencies.

Therefore, we conducted a case study in the General Coordination of Marine and Coastal Undertakings (CGMAC) from the Brazilian Institute of Environment and Natural Renewable Resources (IBAMA). Two of its units were the focus of this research, the Oil and Gas Exploration Coordination and the Oil and Gas Production Coordination. These are based in Rio de Janeiro since 1998, where most of oil and gas operators have their headquarters. Their primary task is to analyse and condition requests for permission to install and operate offshore oil and gas projects in Brazil. CGMAC is subordinate to the Environmental Licensing Directory of IBAMA, which conducts all federal environmental permitting in the country.

\section{THEORY: ENVIRONMENTAL GOVERNANCE - FEATURES AND FUNCTIONS}

Environmental governance operates within social-ecological systems (SES), where society is embedded in ecosystems and intertwined relations lead to changing environmental results. Two areas of research serve as the grounding for SES science: systems approach and adaptative management; and the study of institutions and property rights (Berkes and Folke 1998). Furthermore, it focuses on having an integrated perspective of humans-innature and the concept of resilience (Folke et al. 2016). Resilience is a concept that reflects the capacity of a system to: cope with change, maintaining its functions and structures; self-organize; and progressively develop its capacity of learning and adaptation (Berkes, 2005).

According to Ostrom (2009a) there are four core subsystems of SES which interact to produce outcomes at the SES level, which in turn provide feedback to affect these subsystems and their components, as well other larger or smaller SES: governance systems (e.g. environmental legislation 
and agencies); resource systems (e.g. marine ecosystems); resource units (e.g. corals, fish); and users (e.g. fishers, oil and gas companies). Each of those has several associated variables that condition possible interactions and outcomes of SES - together with the existing social, economic and political settings. The interplay of these different elements in multiple levels leads to adaptive cycles of what one may call a panarchy. This term is a representation of a set of adaptive cycles that nest within each other across space and time scales (Holling, 2001).Environmental governance is about addressing the problem of fit between ecosystems and institutions (Folke et al. 2007) and trying to coordinate actors to meet this challenge.

Institutions, in turn, are humanly devised constraints that structure social, political and economic interaction (North, 1991). These may be both formal (e.g. laws and property rights) or informal (e.g. traditions or codes of conduct). Moreover, a degree of stability and, therefore, path dependence meaning that previous conditions mould significantly further developments - characterize these systems. In this sense, the study of institutional change is key to understanding present conditions and acting to improve them. It has resulted in a variety of theoretical approaches that emphasize different processes, such as the active design of institutions, their spontaneous evolution, as well as the role of habit and learning (Kingston \& Caballero 2009).

In this context, the Institutional Analysis and Development Framework (IAD) aims to organize diagnostic, analytical, and prescriptive capabilities dealing with governance systems (Ostrom, 2011). The IAD is thus a multi-tier conceptual map, which identifies the major types of structural variables that are present to some extent in all institutional arrangements. More specifically, it poses the following set of variables for an institutional arrangement: biophysical conditions; attributes of the community; rules-inuse; evaluative criteria; and its central part, the action situations (Ostrom, 2011). When analysing an institutional issue, one should bear in mind that its configuration results from nested layers of hierarchical rules. Thus, problems may be associated to operational (e.g. policy implementation), collective-choice (e.g. policy formulation) or constitutional tiers (e.g. who may participate in the policy formulation) (Ostrom 2005). In this sense, rules-in-use affect the elements of action situations, for example, position rules delimit how many positions exist and how many actors hold each position (Ostrom, 2009b).

Research efforts related to the IAD frequently face polycentric social systems, characterized by the existence of many decision centres with limited and autonomous prerogatives, operating under an overarching set of rules 
(Aligica \& Tarko, 2012). Highly polycentric governance systems, comprising several agencies and management levels, have been associated to higher environmental output than equivalent monocentric governance (Newig \& Fristsch, 2009). Also noteworthy is that researchers assume that these systems possess a higher ability to adapt to a changing environment and to be less affected in their integrity by sudden changes or failures in one of its parts (Wostl, 2009). Nonetheless, the number of stakeholders involved often implies significant transaction costs, thus actors must be willing to expend considerable amounts of time and energy in seeking and implementing commonly acceptable solutions (McGinnis, 2013). Moreover, power and resource imbalances may hinder the capability of actors to participate, and unless met with a positive strategy of representation and empowerment, this may compromise the effectiveness of the initiative (Ansell \& Gash, 2008). In these contexts, bridging or boundary organization can play an intermediary function and facilitate the sharing of relevant information and the advancement of knowledge (Cash et al., 2006).

Another frequent element in environmental governance systems is an adaptive approach. In a setting of complexity and continuous learning, retaining flexibility and dealing with risk is paramount to action in view of existing uncertainties. Therefore, the principles of experimentation and dynamic adjustment underly adaptive policy-making, resulting from information and knowledge advances, changing ecosystem conditions and stressors, as well as the observed effects of past deeds (Karkkainen, 2004). In this way, institution building, trust building, and social learning - all of which require time and repeated rounds of learning-by-doing - are fundamental (Armitage et al., 2007).

Hence, environmental governance aims to fulfil several functions, including: regulation of resource use and distribution of its benefits; provisioning; monitoring; enforcement; conflict resolution; and collective choice (Paavola, 2007). It should also meet other requirements, such as to enable technical, physical and institutional infrastructure - as well as encourage adaptation and change (Dietz at al., 2003). Each governance arrangement will organize these functions differently and implement distinctive strategies to meet existing requirements, according to its specific attributes and scale. Even so, at the heart of the choices to be made are political decisions (Graaf et al., 1996) which will result in different developmental paths. Thus, environmental governance deals with equity and justice, comprising distributive issues related to alternative scenarios of environmental change. Furthermore, it involves a plurality of values related to the co-existence of incommensurable ethical premises of behaviour, resulting 
in different understandings of what is just (Paavola, 2007). Therefore, it is impossible to compare alternative solutions in equal standards, meaning that procedural justice is essential to ensure the legitimacy of the system - since it provides the recognition of affected parties' interests.

Taking environmental governance challenges and purposes into account, the state remains a key factor in this equation due to the necessity of arbitrating the distribution of costs and benefits related to environmental change (Lemos \& Agrawal, 2006). Gunningham (2009) provides a minimum set of three roles for governments in collaborative arrangements:

- Definitional guidance, orienting the scope and intentions of efforts as well the structure of the governance system;

- Participatory incentives, be they positive (e.g. inducements) or negative (e.g. punitive sanction);

- Enforcement capability, ensuring evaluative criteria, performance indicators and other means to guarantee the assessment and fulfilment of objectives.

Ultimately, how the public sector participates in environmental governance systems is a chief element of its outcomes and depends on effective methods and adequate resources.

\section{METHODS}

This work takes an exploratory approach to research how regulatory agencies participate in environmental governance systems. Therefore, a case study was conducted, using sources of evidence commonly applied in this methodology: interviews; documentation; archival records; direct observation; and participant observation (Yin, 2001).

The case departs from the experience of two public environmental units from $C G M A C$. It regards the environmental governance of offshore oil and gas projects in Brazil, which is circumscribed in the larger system of coastal and marine environmental protection. The focus on this system was established due to the breadth of the theme and to the authors' accessibility to related sources of data.

To address relevant theoretical discussions, the research design was based on the Institutional Analysis and Development Framework, as outlined by Ostrom (2011), considering:

- The main attributes of an action situation;

- external variables, including biophysical conditions, attributes of community and rules-in-use that affect each element of the action situation 
- existing interactions and possible outcomes; and

- evaluative criteria.

Thus, the IAD framework was the main methodological reference for this study, supporting the analysis of results and the identification of key findings. Remarkably, the focus of this work was not a typical common pool resource, such as forests or fisheries (Agrawal, 2004), as seen in similar applications of the IAD, but a unit of public administration. This draws upon the acknowledgement that environmental agencies may be characterized by the attributes of subtractability of use and difficulty of exclusion as defined by Ostrom (2009b).

We considered all collected data to ensure the triangulation of information. Nonetheless, the fundamental elements of the study were the interviews and questionnaires, where a proper focus could be directed to the topics of interest and tailored to address the IAD framework. Accordingly, the interviews were semi-structured and followed a script with four main subjects:

- Institutional background and evolution - considering the history, developments and learning mechanisms of the governance system;

- Environmental permitting's role in the environmental governance system - identifying external variables, existing controls and evaluative criteria;

- Institutional details - such as forms of organization, formal and informal practices, as well as feedback mechanisms and access to resources;

- Critical aspects - which addresses key problems, conflicts and positive characteristics.

The script also enabled the discussion of other topics present in the literature related to successful governance arrangements, such as the presence of graduated sanction instruments and other design principles of sustained institutions (Ostrom 2009b). Moreover, interviewees included over a dozen individuals from several organizations, featuring: other public agencies (e.g. the National Oil and Gas Agency - $A N P$ ); environmental consulting firms; representatives from the oil and gas industry; $C G M A C$ 's coordinators and environmental analysts; other divisions of IBAMA; and companies providing services offshore. Appendix A shows a brief qualification of interviewees as well as the reference code used throughout this text. Each interview was summarized and shared with the respective participant for eventual correction or complementation.

Furthermore, a questionnaire was sent to both $C G M A C^{\prime}$ 's oil and gas units, with two main topics: how the work agenda is defined; and which main 
interests does it suit. Both questions had open answers and multiple-choice options. Twenty-five anonymous answers were received. These questions were also presented to the coordinators in office during interviews for commentary. Again, we summarized and shared each interview for eventual correction or complementation. Appendix B shows the questionnaire used and the reference code associated with these interviews.

\section{RESULTS AND DISCUSSION}

In Brazil, environmental issues remain as a secondary issue in the political setting (Cavalcanti 2004). As such, oil and gas exploration was conducted for a long time without proper environmental assessment (CGP1, CGP3, CGP6) - even after the consolidation of the National Environmental Policy Act, which established the necessity that potentially polluting activities undergo this process. Only when the market for these undertakings was opened to private companies, in the end of the 1990s, was a public unit was established to license new projects and regularize existing developments. Since then, Brazil has established itself as one of the world's main oil producers, having reached the mark of 2.6 million barrels/day in 2017, 95.2\% of which from offshore platforms (ANP 2018).

Meanwhile, the governance structure also grew, based chiefly on two organizations, ANP and IBAMA (Bredariol \& D'avignon, 2018). Thus, the regulatory configuration separated fomentation interests from environmental concerns. On the other hand, it created coordination obstacles. This resulted in the auction of exploratory oil areas without previous environmental assessment. Thus, leased oil and gas fields broadly overlap with vulnerable deep-sea ecosystems of high biological and ecological relevance, including cold-water corals, submarine canyons and slope sediments (Almada \& Bernardino, 2017). Consequently, undertakings might not obtain an environmental permit to conduct the activity of interest, despite having purchased this right from the government. After the first time this happened, a series of remediation measures followed (Mariano \& La Rovere, 2007), including two pieces of legislation aiming to define the main requirements for environmental permitting (Brasil, 2011) and how this relates to strategic assessments of exploration areas, which should occur before auctions (Brasil, 2012a). Nonetheless, the first strategic assessment of this kind started only in 2015 and none has been finished as of this date. Therefore, this institutional conflict remains unsolved and causes insecurity in the governance arrangement (CGP1, GOV3, ES1). 
The related action situation, which regards the decision over an environmental authorization for an oil and gas project, is influenced by two central elements: the information available, which is scarce due to the complexity of the system and limited existing research efforts, especially for the deep sea (Sweetman et al., 2017); and demands of interested parties, such as fishing communities, government agencies and ministries, as well as nongovernmental organizations. Thus, technical opinions are elaborated in view of conflicts regarding different interests related to marine use, such as fishing, oil exploration or habitat conservation. A recent process showcased this when Greenpeace started a worldwide campaign to pressure IBAMA to deny environmental permits to drill in a region near the mouth of the Amazon river. Following, when technical opinions indicated several shortcomings of the environmental study presented, IBAMA denied the permit for this undertaking (documentation - Despacho no 3912994/2018-GABIN SEI).

The main action situation of this setting relates to the following rulesin-use. Permitting authorities issue technical opinions regarding requested environmental permits (scope rule). Authorities assign environmental analysts with the elaboration of these documents (choice rule); such analysts enter the public service through public federal exams (boundary rule). These exams also function as the main instrument defining the number of positions available and must be approved by the federal legislative and executive bodies (position rule). Technical opinions should be conclusive and support the manifestation of the unit's coordinator and the general coordination, which report to the licensing director and, ultimately, to $I B A M A^{\prime}$ 's president (aggregation rule). The project evaluation is based on an environmental impact assessment (EIA) which is publicly available, as well as the related permitting process, except for cases for which the legislation restricts access by those who formulate requests to classify information (information rule). This impact assessment considers characteristics of the activity and its most significant environmental impacts - a summary of the main aspects involved is provided by Cordes et al. (2016). The EIA qualifies the permitting procedure and supports the definition of clauses that condition the permits granted, including the implementation of environmental projects and best practices for pollution prevention. Failure to fulfil these obligations result in penalties (e.g. fines, permit suspension) that may also ensue from the substantiation of unpredicted impacts or operational characteristics (pay off rule).

In Brazil, the EIA procedure has a series of shortcomings, relating, among others, to the following: structural and organizational deficit in the environmental agencies; partiality in the technical assessments, since 
the project's proponent hires the consulting companies; a poor integration between environmental impact analysis and risk assessments; and limited public involvement (Naime, 2017). Nonetheless, it is one of the main instruments of the national environmental policy, and despite its limited scope, plays a major role in the public environmental agenda (Lustosa et al., 2010). The experience of the oil and gas permitting units in particular shows some distinct qualities such as the follow up of ongoing projects and the establishment of technical guidelines that undergo public consultation (CGP1, CGP4, CGP5, CGP6, GOV4, ES3), constituting a dynamic process which incorporates learning from past activities (Cruz \& Montaño, 2016). An emblematic example is the IBAMA norm for environmental education programs (BRASIL, 2012b). After a series of permitting processes and related follow up activities, environmental analysts drafted a technical note to indicate directives for environmental education projects presented by the offshore industry as mitigation measures for assessed impacts. After public consultation and internal review, IBAMA published the technical note in 2010 (documentation - NOTA TÉCNICA CGPEG/DILIC/IBAMA № 01/10). This brought predictability to the oil and gas companies and provided the qualification of related projects, which led IBAMA to further develop the standard and make it applicable to all licensed undertakings.

Furthermore, the institutional setting has the following key external variables: the development of technologies and definition of new industry benchmarks (e.g. new oil recovery equipment); the state of the ecosystems involved (e.g. information from environmental monitoring programs); the structure available for follow-up activities and data integration (e.g. the existence of functional environmental databases); the political and economic context (e.g. federal policy initiatives, crude oil prices); and third-party interaction (e.g. cooperation agreements with $A N P$, development of new regulations with the Ministry of the Environment, demands from the Public Prosecution Office).

This action situation has feedback loops which, due to the lack of proper administrative structure and information systems (CGU 2014), operate fundamentally through the environmental analysts (CGP1, CGP4, ES1, ES2). Hence, results from ongoing environmental projects, on-site inspections and oil and gas developments enable learning and the change of existing practices (CGP2, CGP3, CGP6, ES3).

The case of water monitoring projects is useful to illustrate these feedback loops. Limited sources of data regarding offshore water characteristics together with the concern over potential impacts from produced water discharge to the sea (BAKKE et al., 2013) led to the requirement of water 
monitoring projects for every oil and gas production platform licensed. Due to the size and complexity of the marine environment, these projects did not produce enough data to enable robust conclusions. Following this observation, the institutional arrangement evolved to enable regional environmental monitoring programs, integrating results from multiple platforms and distinct sampling strategies. Currently, areas with a concentration of production platforms have integrated projects, such as the Campos Basin where Petrobras alone develops: regional monitoring of water, sediment and biota quality, aiming to improve the understanding of the marine environment; a focused project to monitor water and sediment quality near representative productions facilities, with the objective of assessing potential impacts from the activity; and minor water quality monitoring, near every production platform that verify effects of produced water discharge (documentation - IBAMA Process no 02022.000490/2010). Results of these projects have influenced the content of recent terms of reference for the preparation of EIAs, enabling more focused environmental studies (documentation - Term of Reference IBAMA no $0687943 \mathrm{SEI}$ ).

Such continuous improvement, linked to an adaptive management strategy, depend on a certain degree of autonomy (CGP1, CGP4, ES2, ES3). This is related to the capability of enforcing the conditions established for the operation of undertakings and, eventually, negating new requests that do not meet environmental standards. The political context sometimes undermines this quality, limiting the resources available for field activities and even granting permits in discordance with the technical opinions issued (e.g. documentation - Operation Permit IBAMA n ${ }^{\circ}$ 1348/2016 was granted despite the recommendations of the technical opinion PAR. 02022.000454/2016-23 CPROD/CGPEG/DILIC/IBAMA). Such events are result of political pressures over IBAMA, whose presidency is appointed freely by the Environmental Minister and, thus, is a position that rests in the power of the Brazilian president. Institutional stability is an important attribute in this sense, enabling long term planning and trust building. Thus, external variables limit the operational space available, on occasions following a perception that the Brazilian environmental permitting process is an administrative mechanism to validate and legitimate projects and activities, rather than a process to assess, evaluate, and decide about impacts (Naime, 2017).

Interestingly, according to interviews and observation, the body of public officers organizes itself in a way that promotes robustness and unity (CGP1, CGP2, CGP3, CGP4, CGP5, CGP6, GOV2). This happens through a mostly horizontal management of the decision making, in which all 
participants have a voice and search collaboratively for a consensus-oriented conduct in each main phase of the process. In a sense, it follows precepts of adaptive co-management, where the aim is to build adaptive capacity and institutional resilience, using decentralization and devolution as a strategy of institutional design (ARMITAGE et al., 2007).

Furthermore, a hybrid working structure, where the staff is officially allocated in teams related to type of projects (e.g. drilling, production) and informally cooperate in thematic groups (e.g. emergency response, pollution control), assists the sharing of information and the consolidation of commons procedures (CGP1, CGP2, CGP3, CGP5). Thus, the formal and informal institutions complement each other through different means of conflict resolution, knowledge management and resource monitoring.

The resulting governance system is marked by polycentricity. Not only in the broader frame, with environmental outcomes depending on actions from $A N P, I B A M A$, affected communities, non-governmental organizations, the industrial sector and other stakeholders, but also internally - where the public administration operates based on multiple criteria, including those defined informally in different working groups (CGP2, CGP3, CGP4, CGP6).

The questionnaire results corroborate the finding that the work agenda is an outcome of multiple factors, with $70.9 \%$ of respondents indicating that it was composed of all suggested options (coordinator requests, working group tasks, follow-up from previous work, own initiative) and only $20.8 \%$ selecting only one item ( $8.3 \%$ coordinator requests, $8.3 \%$ own initiative, $4.2 \%$ follow-up from previous work). Descriptions of the agenda-setting process had in common multiple sources of work, such as pointed out in the following response: "Today it is a little of each of them, with a certain preponderance of "own initiative". Generally speaking, unless urgent demands come from my boss, I set my own agenda according to my understanding of priorities."

The results from the second question also point to multiple elements related to the work performed. Over $70 \%$ of participants, when faced with the question of which interests their work generally addresses, responded with "society at large" or a combination of the available options. The coordinators, on the other hand, observed that they had to manage too many issues and a large workforce, being unable to develop the whole work agenda (COG1, COG2, GC1). In this context, they highlighted that the oil and gas sector is very organized and, thus, can lobby effectively for their interests (COG2, CG1) and often constitute the main group with which they interact (COG1). 
Figure 1 presents a compilation of the answers received regarding the second topic. Written responses on the matter, qualifying how each factor was pertinent to their jobs, were similar to the following reply: "I think I mainly attend to society at large by seeking to work for environmental protection, which is IBAMA's mission. But at the same time, I understand that my work must meet the industry's interests, since IBAMA provides services that must have predictability and transparency (...) as well as the affected communities' interests, who have in the environmental permitting a tool to deal with the impacts to which they are subject."

In a sense, the environmental permitting serves multiple interests and must not only guarantee that offshore oil and gas projects don't jeopardize critical ecosystem services, but also consider knowledge gaps, provide input for new legislation, and meet demands from the industry and affected parties (CGP1, CGP4, GOV1, ES1).

Figure 1 - Responses to the second topic of the questionnaire sent to environmental analysts.

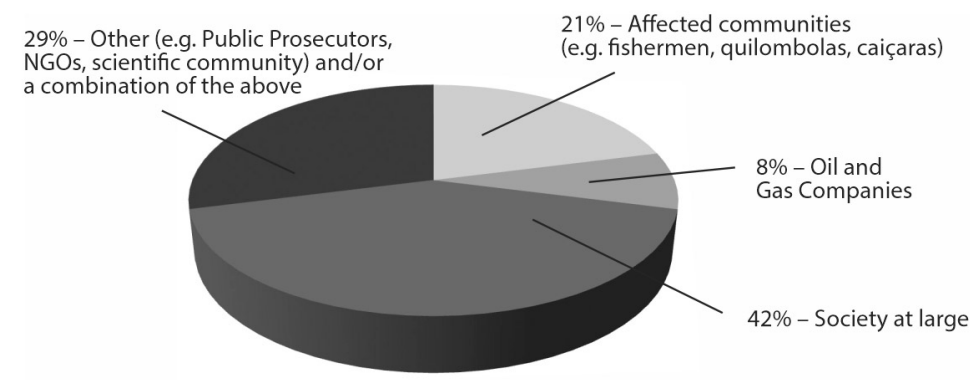

JUuice. Mutilvi s Uvvil Ilyuite

Moreover, the governance system deals with change through supported dialogue (CGP1, CGP3, GOV3, GOV4, ES1). One example of this was a public program that brought together different spheres of the government and representatives of the industrial sector to identify improvement opportunities in the environmental permitting of oil and gas undertakings, including private sector responsibilities (PROMINP 2014). Important factors enabling a joint institutional construction noted in interviews are: the limited number of oil companies; the similarity of projects and their lengthy time horizon; and the location of most interested parties in the Rio de Janeiro region (CGP1, CGP3, CGP4, ES2). In this context, the environmental permitting bureau often operates mediating and facilitating the co-production of knowledge in order to make it relevant to policy and action. 
Another factor related to the observed institutional development is the collaboration between civil servants (CGP1, CGP2, CGP3, CGP4, CGP6). Ansell and Gash (2008) suggest that collaborative efforts depend on faceto-face dialogue, trust building, and the development of commitment and shared understanding. Furthermore, existing interdependence favours such collaboration and requires time to be effective. These are elements present in the studied institutional setting, being exercised in the thematic working groups and other forums and generate a commitment that is key to a better performance of the units (CGP1, CGP2, CGP3). Moreover, Ostrom (2009b) describes many of these aspects as attributes of micro-situations that affect the level of cooperation that participants achieve: communication is feasible with the full set of participants; reputations of participants are known; high marginal per capita returns exist as well as entry or exit capabilities; longer time horizon; and agreed-upon sanctioning capabilities are present. Considering the institutional situation, in which about 70 civil servants work together with reasonable autonomy for individual initiatives, only the last attribute is genuinely lacking. Archival records of 2015 indicate that environmental analysts have been working in IBAMA with oil and gas permitting for over five years on average and a significant proportion $(>30 \%)$ has been in this position for more than ten years. The related legislation guaranties reasonable stability, since dismissal is only possible in face of a predefined set of criteria and must follow a lengthy review procedure. On the other hand, the only possible sanctions are not agreed upon and may assume the form of formal negative evaluation conditioning a reduction of wage or informal actions (e.g. uncooperative behaviour).

This kind of social capital - understood as relations of trust, reciprocity, common rules, norms, sanctions, and connectedness in institutions - has been regarded as the glue for adaptive capacity and collaboration (Folke et al. 2005). However, it is not immune to crises and external pressures. The current Brazilian context, of fiscal crisis and political dispute (Santos \& Szwako, 2017) has hampered the environmental governance system. It curtailed technical decision making and implied in unstructured organizational change (Villardo \& Barbosa, 2018). Even so, the complexity of the institutional arrangement, comprising different actors and procedures, should endow it with some robustness and resilience (Bredariol \& Vinha, 2015). Analysts judge polycentric institutions, with modest overlaps in authority and capability, as inefficient because they look messy and are nonhierarchical in structure, but they help provide a repertoire of principles that can be drawn on by users to aid in the crafting of new institutions to cope with changing situations (Folke et al., 2005). 
Evaluating the results of environmental governance systems is challenging, since incommensurable perspectives exist. Nonetheless, it is important to identify positive features. In this sense, Ostrom (2011) provides six evaluative criteria: economic efficiency; fiscal equivalence; redistributive equity; accountability; conformance to values of local actors; and sustainability. The first parameter cannot be assessed by the data obtained in this study. The next two are tenable by the institutional arrangement insofar as the project proponents pay for all costs related to the permitting process and vulnerable populations are a focus of the EIA. Thus, several undertakings have mitigating measures related to these groups, such as the development of compensatory projects for low income fisherman communities, which have a say in the elaboration of these projects and receive tangible benefits (e.g. ice factories, training courses, safety improvements for the fishing fleet) (documentation - IBAMA Process no 02022.003014/2005). Moreover, regarding accountability and conformance to values of local actors, both are constricted by limited specific informal initiatives - such as preliminary public meetings to explain projects to communities in areas of special interest - or formal less productive procedures, as public hearings with no binding outcomes (CGP1, CGP2, CGP6, GOV3). Lastly, in respect to the sustainability of the system, this rests mainly in the collaborative efforts, which allow for adaptability and the search for effectiveness. A related feature is the complementarity of formal and informal institutions that enables a higher resilience of the system, supported also by other organizations (e.g. ANP, Public Prosecution Office) that demand and cooperate in the advancement of the environmental agenda.

\section{CONCLUSION}

This study has allowed the identification of central challenges, functions and features of one specific environmental governance system. Thus, the following conclusions should not be promptly generalized to other situations but may be used to provide insights and aid in problem solving or institutional design.

Firstly, an environmental governance system should consider the interest of affected parties and address the various existing concerns, aiming to enhance environmental quality. This will favour involvement and cooperation among stakeholders. In this context, public offices often must provide a common information base for communication, promote participation and guarantee compliance to established rules. Furthermore, multiple criteria should be the basis for the dialogue necessary to enable 
such efforts, involving not only technical elements (e.g. ecosystem state information), but also political aspects (e.g. redistributive equity) and support accountability. Hence, cooperation is a key feature since it assures the function of enabling participation, being favoured by functional communication between participants, agreed upon spheres of action and a longer time horizon. The internal situation of the studied coordinations former CGPEG, specifically, achieves cooperative engagement through: a shared understanding of the units' goals; interdependence between actions; activities that promote the integration of the personnel (e.g. workshops for technical discussion and guideline development); among other elements (CGP 1, CGP 2, CGP 3, CGP5, CGP 6). Moreover, the limited number of participating actors and the fact that most interested parties where located in the same region, centred in Rio de Janeiro, concentrated capacity building efforts and reduced transaction costs, allowing the development of a continuous supported dialogue.

Next, the nature of the existing interaction between stakeholders is a central variable in the governance system. Structured and long term means of joint institutional building can lead to continuous improvement and benefit adaptability through an experimentation and learning process. Flexible institutions and enabling legislation create opportunities for adaptive co-management and self-organization (Folke et al., 2005). In this sense, it is interesting to note that the studied governance system shows a degree of polycentricity, having numerous formal and informal decision centres that slightly overlap in a mostly complementary fashion. Moreover, it participated in initiatives where the operational rules under which it functions were elaborated, such as the legislative framework for the environmental permitting of offshore oil and gas activities, resulting in the design of institutional innovations such as regional environmental studies and projects that serve multiple undertakings (Brasil, 2011). These novel instruments have brought more effectiveness to the environmental permitting process, despite the lack of optimal information systems (e.g. integrated databases) (CPG 1, CGP 4, CPG 6, GOV 3, ES 1, ES 3). Thus, stability is a key feature which relates to the function of institution building and continued learning. A quality that makes such institutional evolution possible is the permanence of civil servants in the public administration. It facilitates the learning process, providing qualified work based on hands-on experience and continuous improvement of existent standards. Furthermore, insofar as collaboration depends on trust building, this permanence assures that some auxiliary factors may function beneficially, such as the knowledge of the reputation of participants. 
Finally, environmental governance, as an instrument for collective choice, must deal with power asymmetries, political preferences and knowledge gaps in a complex setting. Therefore, it depends on the public environmental organization retaining some degree of autonomy to articulate and arbitrate other actor's interests. In the case studied, this implies the capacity of guaranteeing the implementation of projects as defined in the permitting process as well as the possibility of declining requests that do not meet applying criteria. In this sense, the post-permit phase, with monitoring of project implementation and enforcement of established requirements, may provide the means necessary to organize valuable information and is essential to enable adjustments and learning in the related processes. Consequently, autonomy is a key feature associated to the function of establishing operational limits and guaranteeing compliance to defined restrictions. This capacity rests on practical sanctioning mechanisms and a reasonable set of checks and balances, such as the opposing pressures of industry influence via government and society's demands from the Public Prosecution Office. Moving further, the state should aim to broaden its ties with society, enabling effective accountability and participation procedures in governance systems. Figure 2 displays the key functions and features identified in this study.

Figure 2 - Key Functions of an Environmental Governance System and Related Features of the Public Administration

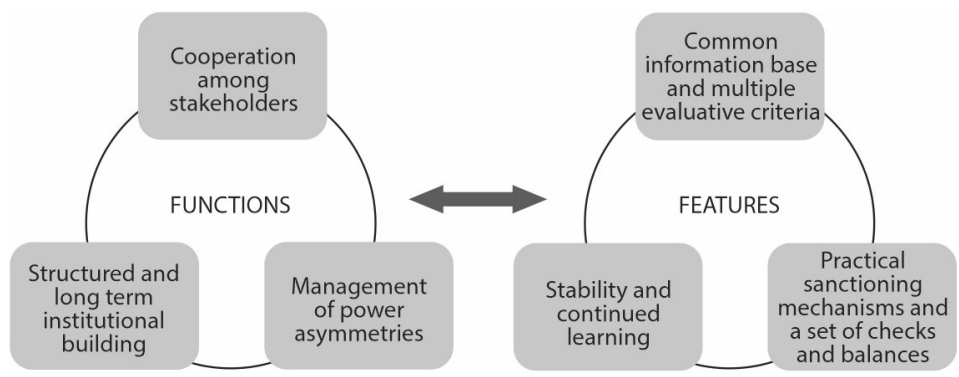

Source: Author's own figure

One final remark is that the public administration, when faced with multiple demands related to diverse interests, may well behave as a common pool resource, with the traits of subtractability of use and difficulty of users' exclusion. As seen in this article, work in public offices can arise from multiple sources and addresses society at large. Thus, public administration might also share principles related to common pool resource governance, 
benefiting from attributes such as clear boundaries between legitimate users and nonusers, as well as collective-choice arrangements in which individuals affected are authorized to participate in making and modifying the rules of the governance system.

\section{Referências}

AGRAWAL, A. Sustainable Governance of Common-Pool Resources: Context, Methods, and Politics. Annual Review of AnthropologY, v. 32, p. 243-62, 2004.

ALIGICA, P. D.;TARKO, V. Polycentricity: From Polanyi to Ostrom, and Beyond. Governance, n. 25, p. 237-262, 2012.

ALMADA, G. V. M. B.; BERNARDINO, A. F. Conservation of Deep-Sea Ecosystems within Offshore Oil Fields on the Brazilian Margin, SW Atlantic. Biological Conservation, n. 206, p. 92-101, 2017.

ANP - Agência Nacional do Petróleo Gás Natural e Biocombustíveis. Anuário Estatístico Brasileiro Do Petróleo, Gás Natural e Biocombustiveis 2018. Anp/ Mme, 2018. Available at: <http://www. anp.gov.br/images/publicacoes/ anuario-estatistico/2018/anuario_2018. pdf>Accessed March 21, 2019.

ANSELL, C.; GASH, A. Collaborative Governance in Theory and Practice. Journal of Public Administration Research and Theory, v. 18, p. 543-571, 2008.

ARMITAGE, D.; BERKES, F.; DOUBLEDAY, N. Adaptive Co-Management: Collaboration, Learning, and Multi-Level Governance. Canada: UBC Press, 2007.

BAKKE, T.; KLUNGSOYR, J.;SANNI, S. Environmental Impacts of Produced Water and Drilling Waste Discharges from the Norwegian Offshore Petroleum Industry. Marine Environmental Research, n. 92, 154169, 2013.

BERKES, F. Conexões institucionais transescalares. In: VIEIRA, P. F.; BERKES F.; SEIXAS C. S. Gestão integrada e participativa de recursos naturais: conceitos, métodos $e$ experiências, Florianópolis: Ed. Secco/APED, 2005. p. 293-332.

BERKES, F.; FOLKE, C. Linking social and ecological systems: management practices and social mechanisms for building resilience. Cambridge, UK: Cambridge University Press, 1998.

Brasil. IBAMA - Instituto Brasileiro do Meio Ambiente e dos Recursos Naturais Renováveis. 2012b. Instrução Normativa $n^{\circ} 2$, de 27 de março de 2012. Estabelece as bases técnicas para programas de educação ambiental apresentados como medidas mitigadoras ou compensatórias, em cumprimento às condicionantes das licenças ambientais emitidas pelo Instituto Brasileiro do Meio Ambiente e dos Recursos Naturais Renováveis - IBAMA. Diário Oficial da União, Brasília, 29 de março de 2012.

Brasil. MMA - Ministério do Meio Ambiente. 2011. Portaria $\mathrm{N}^{\circ} 422$, de 26 de outubro de 2011. Diário Oficial da União, Brasília, 26 de outubro de 2011.

Brasil. MMA / MME - Ministério de Meio Ambiente / Ministério de Minas e Energia. 2012a. Portaria Interministerial $N^{\circ} 198$ de 5 de abril de 2012. Diário Oficial da União, Brasília, 9 de abril de 2012.

BREDARIOL, T. O.; VINHA, V. G. Instituições e Governança Ambiental: Uma Revisão Teórica. Revista Iberoamericano de Economia Ecológica, n. 24، p. 153-162, 2015. Available at: https://bit.ly/2QgwpmF. Accessed: March 21, 2019. 
BREDARIOL, T. O.; D'AVIGNON, A.

L. Institutions and environmental governance: The case of environmental permitting for offshore oil and gas projects. Ambiente e Sociedade, n. 21, 2018, p. 22.

CASH, D. W.;ADGER,W. N.; BERKES, F.; GARDEN, P.; LEBEL, L.; OLSSON, P.; PRITCHARD, L.; YOUNG, O. Scale and cross-scale dynamics: governance and information in a multilevel world. Ecology and Society, v. 11, n. 2, p. 8, 2006. Available at: https://bit.ly/3htai8o. Accessed: March 21, 2019 .

CAVALCANTI, C. Economia e Ecologia: Problemas Da Governança Ambiental No Brasil. Revista Iberoamericana de Economia Ecológica, n. 1, p. 1-10, 2004.

CGU. Controladoria Geral da União. Relatório de Auditoria Anual de Contas: IBAMA - Sede, Exercício 2012.2012. Available at: https://bit.ly/2EpWZHc. Accessed March 21, 2019.

CORDES, E. E.; JONES, D. O.; SCHLACHER, T. A.; AMON, D. J.; BERNARDINO,

A. F.; BROOKE, S.; CARNEY, R. et al. Environmental Impacts of the Deep-Water Oil and Gas Industry: A Review to Guide Management Strategies. Frontiers in Environmental Science, v. 4, n. 58, 2016.

CRUZ, F. B.; MONTANO, M.Evidências de aprendizagem na AIA: estudo de caso para o setor de óleo e gás no Brasil. $3^{\circ}$ Congresso Brasileiro de Avaliação de Impacto.Ribeirão Preto: USP, 2016.Available at: https://bit. ly/3aNTuqf. Accessed: March 21, 2019.

DAVIDSON, D. J.;FRICKEL, S.

Understanding Environmental

Governance: A Critical Review.

Organizational Environment, n. 17, 471-492, 2004.

DIETZ, T.; OSTROM, E. \& STERN, P. C. Struggle to Govern the Commons. Science, 302 (5652), 1907-12, 2003. ENROTH, H. Governance: The Art of Governing after Governmentality. European Journal of Social Theory, v. 17, n. 1, p. 60-76, 2014.
FOLKE, C.; BIGGS, R.; NORSTROM, A. V.; REYERS, B.; ROCKSTROM, J. SocialEcological Resilience and Biosphere-Based Sustainability Science. Ecology and Society, v. 2, n. 3, 41, 2016.

FOLKE, C.; HAHN, T.; OLSSON, P.; NORBERG, J.Adaptive Governance of Social-Ecological Systems. Annual Review of Environmental Resources, v. 30, n. 1, p; 441-473, 2005.

FOLKE, C.; PRITCHARD, L.; BERKES, F.; COLDING, J.; SVEDIN, U. The Problem of Fit between Ecosystems and Institutions: Ten Years Later. Ecology and Society12 (1): 30, 2007.

GRAAF, H. J.; MUSTERS, C. J.M.; KEURS, W. J. Sustainable Development: Looking for New Strategies. Ecological Economics, n. 16, p. 205-216, 1996.

GUNNINGHAM, N. The New Collaborative Environmental Governance: The Localization of Regulation. Journal of Law and Society, v. 36, n. 1, p. 145-166, 2009.

HOLLING, C. S. Understanding the Complexity of Economic, Ecological, and Social Systems. Ecosystems, n. 4, p. 390405, 2001.

KARKKAINEN, B. C. Post-Sovereign Environmental Governance. Global Environment and Politics, v. 4, n. 1, 72-96, 2004.

KINGSTON, C.; CABALLERO, G. Comparing Theories of Institutional Change. Journal of Institutional Economics, v. 5, n. 2, p. 151-180, 2009.

LEMOS, M. C.; AGRAWAL, A.Environmental Governance. Annual Review of Environmental Resources, v. 31, n. 1, p. 297-325, 2006.

LUSTOSA, M. C.; CÁNEPA, E. M.; YOUNG, C. E."Política ambiental."InEconomia do meio ambiente: teoria e prática, edited by: MAY, P. H.Rio de Janeiro: Elsevier, 2d ed., 2010, p. 33-48. 
MARIANO, J.; LA ROVERE, E. Oil and Gas Exploration and Production Activities in Brazil: The Consideration of Environmental Issues in the Bidding Rounds Promoted by the National Petroleum Agency. Energy Policy, n. 35, p. 2899-2911, 2007.

MCGINNIS, M. D. Costs and Challenges of Polycentric Governance: An Equilibrium Concept and Examples from U.S. Health Care. Conference on Self-Governance, Polycentricity, and Development, Renmin University of China, Beijing. SSRN, 2013. NAIME, A. An Evaluation of a Risk-Based Environmental Regulation in Brazil: Limitations to Risk Management of Hazardous Installations. Environmental Impact AssessmentReview, n. 63, p. 35-43, 2017.

NEWIG, J.; FRITSCH, O.Environmental Governance: Participatory, Multi-Level - and Effective?.Environmental Policy and Governance, v. 19, n. 3, p. 197-214, 2009.

NORTH, D. C. Institutions". Journal of Economic Perspectives, v. 5, n. 1, p. 97-112, 1991.

OSTROM, E. Understanding institutional diversity. Princeton: Princeton University Press, 2005.

OSTROM, E.A General Framework for Analysing Sustainability of SocialEcological Systems. Science, v. 325 (5939), p. 419-22, 2009a.

OSTROM, E. Beyond markets and states: polycentric governance of complex economic systems. Nobel Prize Lecture, December 8, 2009. 2009b. Available at: https://bit.ly/31rVO3f. Accessed: March 21, 2019.
OSTROM, E. Background on the Institutional Analysis and Development Framework. Policy Studies Journal, v. 39, n. 1, p. 7-27, 2011.

PAAVOLA, J. Institutions and Environmental Governance: A Reconceptualization. Ecological Economics, v. 63, n. 1, p. 93-103, 2007.

PROMINP-Programa de Mobilização da Indústria Nacional de Petróleo e Gás Natural -. Relatório Final: Aperfeiçoamento do Processo de Licenciamento Ambiental. Available at: https://bit.ly/3lbGEGS. Accessed: March 21, 2019.

SANTOS, F.; SZWAKO, J. Da Ruptura à Reconstrução Democrática No Brasil. Saúde em Debate, n. 40, p. 114-121, 2017. SWEETMAN, A. K., THURBER, A. R., SMITH, C. R., et al. Major impacts of climate change on deep-sea benthic ecosystems, Elementa Science Anthology, v. 5, p. 4, 2017.

VILARDO, C.; BARBOSA, A. F.Can You Hear the Noise? Environmental Licensing of Seismic Surveys in Brazil Faces Uncertain Future after 18 Years Protecting Biodiversity. Perspectives in Ecological Conservation, v. 16, n. 1, p. 1-60, 2018.

PAHL-WOSTL, C. A Conceptual Framework for Analysing Adaptive Capacity and MultiLevel Learning Processes in Resource Governance Regimes. Global Environmental Change, n. 19, p. 354-365, 2009.

YIN, R. K. Estudo de caso: planejamento e métodos. 2.ed. Porto Alegre: Bookman, 2001. 


\section{Appendix A - Brief qualification of interviewees}

$$
\begin{array}{|l}
\hline \text { CGMAC Civil Servants } \\
\hline \text { - CGP1 Manager at CGMAC/DILIC/IBAMA } \\
\text { • CGP2 Technical staff at CGMAC/DILIC/IBAMA } \\
\text { • CGP3 Technical staff at CGMAC/DILIC/IBAMA } \\
\text { • CGP4 Technical staff at CGMAC/DILIC/IBAMA } \\
\text { - CGP5 Technical staff at CGMAC/DILIC/IBAMA } \\
\text { - CGP6 Manager at CGMAC/DILIC/IBAMA }
\end{array}
$$

\section{Other Government Actors}

- GOV1 Manager at COEND/DILIC/IBAMA

- GOV2 Technical staff at DILIC/IBAMA

- GOV3 Manager at ANP

- GOV4 Manager at DPC/Navy

\section{Under Economic Sector}

- $\quad$ ES1 Manager at Brazilian Petroleum, Gas and Biofuels Institute (IBP)

- ES2 Staff at an oil and natural gas services company

- ES3 Staff at a consulting company for environmental impact reports 


\section{Appendix B - Questionnaire and Identification of Interviewees}

Questionnaire Form - Common Pool Resources Research

The research aims to explore how the work agenda is defined and which interests / groups it serves.

1. In general how do you define what you are going to do at work?

- Direct Requests from Coordinator

- Through Technical Working Groups

- Follow-up from previous work

- Own initiative

- Other and / or a combination of the above (please specify in the description below)

Brief description of your work agenda:

2. In general which interests / groups does your work address?

- Society at large

- Affected communities (e.g. fishermen, quilombolas, caiçaras)

- Oil and Gas Companies

- Others (e.g. Public Prosecutors, NGOs, scientific community) and / or a combination of the above (please specify in the description below)

Brief description of which interests / groups your work agenda suits:

Brief qualification of interviewees

(COG1) Coordinator of the Oil and Gas Exploration Coordination

(COG2) Coordinator of the Oil and Gas Production Coordination

(GC1) General Coordination of Marine and Coastal Undertakings 